\title{
EFEKTIVITAS KOMBINASI EKSTRAK DAUN SIRIH MERAH (Piper Crocatum) DAN EKSTRAK BIJI ALPUKAT (Persea americana) DALAM MENGHAMBAT PERTUMBUHAN Candida albicans
}

\author{
Vini Anggraini, Masfufatun Masfufatun * \\ Fakultas Kedokteran Universitas Wijaya Kusuma Surabaya \\ *email: masfufahhabibah@gmail.com
}

Received 19 Oktober 2017

Accepted 28 Nopember 2017

\begin{abstract}
Abstrak
Tujuan penelitian ini adalah untuk mengetahui efektivitas kombinasi daun sirih merah (Piper crocatum) dan ekstrak biji alpukat (Persea americana) dalam menghambat pertumbuhan Candida albicans. Penelitian bersifat eksperimental laboratorium (true experiment) dengan pendekatan post test control group design only. Daun sirih merah dan biji alpukat diekstraksi secara maserasi menggunakan pelarut etanol. Pada masing-masing ekstrak etanol dilakukan uji pendahuluan untuk mengetahui konsentrasi optimum ektrak dalam memnghambat pertumbuhan $C$. albicans. Daya Hambat pertumbuhan C. albicans diuji menggunakan metode difusi. Hasil penelitian menunjukkan bahwa konsentrasi terendah ekstraks daun sirih merah dan biji alpukat yang dapat menghambat pertumbuhaan $C$. albicans masing-masing adalah 10\%. Kombinasi ekstrak daun sirih merah dan ekstrak biji alpukat memiliki daya hambat yang signifikan terhadap pertumbuhan Candida albicans dibandingakan kontrol negatif, kontrol positif dan ekstrak daun sirih merah. Dengan demikian kombinasi ekstrak daun sirih dan biji alpukat etanol berpotensi sebagai antifungi dalam menghambat pertumbuhan $C$. albicans sehingga diharapkan bisa mengurangi prevalensi kandidiasis.
\end{abstract}

Katakunci : daun sirih merah, biji alpukat, Candida albicans,

\begin{abstract}
The purpose of this study was to determine the effectiveness of red betel leaf (Piper crocatum) and avocado seed extract (Persea americana) combination in inhibiting the growth of $C$. albicans. Research is experimental laboratory (true experiment) with post test approach control group design only. Red betel leaf and avocado seeds are extracted by maceration using ethanol solvent. In each ethanol extract, a preliminary test was performed to find out the optimum concentration of extract in inhibiting the growth of $C$. albicans. $C$. albicans growth retardant was tested using diffusion method. The results showed that the extract of red betel leaf and avocado seeds each had the greatest inhibitory concentration at $10 \%$. The combination of red betel leaf extract and avocado seed extract have significant inhibitory effect on $C$. albicans growth compared to negative control, positive control and red betel leaf extract. Thus, the combination of betel leaf extract and ethanol seed has the potential as an antifungal in inhibiting the growth of $C$. albicans so it is expected to reduce the prevalence of candidiasis.
\end{abstract}

Keywords: red betel leaf, avocado seed, Candida albicans, 


\section{Pendahuluan}

Kandidiasis merupakan penyakit yang disebabkan oleh jamur, seperti Candida albicans. Insidens kandidiasis vulvovaginal di Indonesia pada tahun 1979 sebanyak $14 \%$, dan terus mengalami peningkatan menjadi $46 \%$ pada tahun 1997, dan pada tahun 2004, hampir 70\% wanita di Indonesia pernah mengalami keputihan setidaknya sekali dalam hidupnya (Endang, 2003, Prasetyowati, 2009). Dari tahun ke tahun angka kejadian Kandidiasis vulvovaginal semakin meningkat.

Infeksi Candida albicans dapat diterapi dengan penggunaan obat atau sediaan yang fungsinya sebagai anti fungi yang efektif. Golongan obat yang saat ini tersedia untuk pengobatan mikosis meliputi poliena, $\beta$ usitosin, azol, dan griseofulvin. Kenyataan menunjukkan bahwa jenis antifungi relatif lebih sedikit dibandingkan antimikroba lain, selain itu obat kimia sering menimbulkan efek samping yang cukup berat dan harganya mahal, dengan demikian diperlukan penggalian obat alternatif dari tanaman obat tradisional yang secara empiris sudah sering digunakan oleh masyarakat (Rahajeng dan Annisaul, 2014).

Di Indonesia terdapat berbagai jenis tanaman obat tradisional, salah satu jenis obat tradisional adalah sirih merah (Piper crocatum). Tanaman ini memiliki kandungan senyawa kimia seperti $\beta$ avonoid, alkaloid, saponin, tanin, dan minyak atsiri. Minyak atsiri dari daun sirih mengandung minyak terbang (betlephenol), sesquiterpen, pati, diatase, gula dan zat samak dan chavicol yang memiliki daya mematikan kuman, antioksidasi dan fungisida, anti jamur sehingga secara empiris berkhasiat mengurangi sekresi pada liang vagina dan keputihan akut (Rahajeng dan Annisaul, 2014). Ekstrak daun sirih merah mampu mematikan jamur Candida albicans penyebab keputihan akut, dan gatal-gatal pada alat kelamin (Wina dkk, 2015).
Tanaman lain yang memiliki efek antimikroba yaitu biji alpukat (Persea americana). Tanaman ini terbukti efektif menghambat pertumbuhan Candida albicans, Cryptococcus neoformans dan Malassezia pachydermatis melalui teknik mikrodilusi. Hasil Skrining fitokimia yang dilakukan oleh Zuhrotun (2007) terhadap simplisia dan ekstrak etanol biji alpukat menunjukkan bahwa biji alpukat mengandung polifenol, flavonoid, triterpenoid, kuinon, saponin, tanin dan monoterpenoid dan seskuiterpenoid (Dewi dan Sulistyowati, 2013).

Pada penelitian Atika (2010), minyak atsiri kulit batang kayu putih memiliki kemampuan menghambat pertumbuhan Candida albicans yang lebih baik setelah dikombinasikan dengan ekstrak biji jinten hitam (Nigella sativa). Oleh karena itu dalam penelitian ini kami akan menguji efektivitas daun sirih merah (Piper crocatum) dalam menghambat pertumbuhan C.albicans setelah dikombinasi dengan ekstrak etanol biji alpukat (Persea americana).

\section{Metode Penelitian \\ Alat dan Bahan}

Alat yang digunakan dalam penelitian ini adalah cawan petri, jarun Ose, autoklaf, inkubator, pipet ukur, pipet mikro, bunsen, spektrofotometer, laminary flow, tabung reaksi dan blue tips.

Bahan-bahan yang digunakan dalam penelitian ini adalah daun sirih merah dan biji alpukat, media Saboroud Dextrose Agar (SDA), biakan Candida albican, Etanol 96\%, Flukonazol, Kapsul kloramfenikol, DMSO

\section{Prosedur Penelitian \\ Ekstraksi daun sirih merah dan biji alpukat}

Ekstrak daun sirih merah diperoleh dengan cara maserasi. Daun sirih merah segar dicuci dengan air sampai bersih, dipotong-potong, ditiriskan, dikeringkan, kemudian sampel diblender sampai halus. Direndam selama 24 jam dengan Etanol 
96\%. Setelah disaring, filtrate dipekatkan dengan evaporator pada suhu $50^{\circ} \mathrm{C}$ sampai diperoleh ekstrak yang kental

Ekstrak biji alpukat diperoleh dengan cara maserasi. Biji alpukat dicuci dan disikat lembut untuk membersihkan kulit biji yang melekat. Biji dipotong-potong kecil dan tipis kemudian diangin-anginkan di tempat terbuka yang terlindung dari cahaya matahari langsung. Selanjutnya dikeringkan dalam oven dengan suhu $50^{\circ} \mathrm{C}$ selama $2 \times 24$ jam. Setelah kering, biji dihaluskan dengan mesin grinding mesh 20 sampai menjadi serbuk halus, kemudian direndam dalam etanol $96 \%$ selama 24 jam sambil diaduk-aduk. Maserasi dilakukan berulang kali hingga diperoleh larutan jernih. Setelah disaring, filtrat dipekatkan dengan evaporator.

\section{Uji pendahuluan}

Uji pendahuluan ini dilakukan untuk mengetahui konsentrasi optimum ekstrak daun sirih merah dan biji alpukat dalam menghambat pertumbuhan $C$. albicans. Biakan subkultur $C$. albicans diambil dengan mengunakan ose steril ke dalam larutan $\mathrm{NaCl} \quad 0,9 \%$ sampai mencapai kekeruhan yang ekuivalen dengan OD 0,5. Kemudian 0,2 ml suspensi C. albicans dioleskan merata di atas permukaan media agar SDA pada 5 cawan petri. Pada masing-masing cawan petri diletakkan 5 kertas cakram sebagai replika dan ditetesi $0.05 \mathrm{~mL}$ ekstrak daun sirih merah dalam pelarut DMSO dengan konsentrasi yang berbeda 10, 20, 40, 80, dan $100 \%$. Selanjutnya disiapkan 5 cawan petri lagi untuk diisi dengan ekstrak biji alpukat dengan konsentrasi 10, 20, 40, 80 dan $100 \%$. Cawan-cawan petri yang sudah ditetesi dengan ekstrak, kontrol negatif maupun positif diinkubasi pada suhu $37^{\circ} \mathrm{C}$ selama 24 jam. Deameter zona bening yang terbentuk pada sekeliling kertas cakram pada setiap kelompok diukur.
Uji efektivitas kombinasi ekstrak daun sirih merah dengan biji alpukat dalam menghambat pertumbuhan C. albicans

Kombinasi ektrak diperoleh dengan cara mencampurkan ekstrak daun sirih merah dan biji alpukat konsentrasi optimum dengan perbandingan 1:1. Selanjutnya disiapkan 5 cawan petri yang berisi media agar SDA. Kemudian 0,2 ml suspensi $C$. albicans dioleskan merata di atas permukaan media agar SDA pada masing-masing cawan petri dan selanjutnya diletakkan 5 kertas cakram setiap cawan. 0,05 ml DMSO sebagai kontrol negatif, $0,05 \mathrm{ml}$ ekstrak daun sirih merah 50\%, 0,05 ml ekstrak biji alpukat $50 \%, 0,05 \mathrm{ml}$ larutan kombinasi ekstrak daun sirih merah dan ekstrak biji alpukat, dan $0,05 \mathrm{ml}$ larutan flukonazol $25 \mu \mathrm{g}$ sebagai kontrol positif diteteskan di atas kertas cakram pada masing-masing cawan petri. Semua cawan diinkubasi pada suhu $37^{\circ} \mathrm{C}$ selama 24 jam. Deameter zona bening yang terbentuk pada sekeliling kertas cakram pada setiap kelompok diukur dengan jangka sorong.

\section{Analisis data}

Penelitian ini diuji dengan menggunakan uji non parametrik Kruskal Wallis kemudian dilanjutkan dengan uji Mann Whitney. Data diolah dengan SPSS 16.0 for Window.

\section{Hasil dan Pembahasan}

Proses pembuatan ekstrak

Pembuatan ekstrak daun sirih merah dan ekstrak biji alpukat dilakukan dengan menggunakan metode maserasi yang merupakan proses ekstraksi cara dingin dengan menggunakan pelarut etanol $96 \%$. Metode ini dipilih karena merupakan metode yang paling mudah dilakukan, tidak membutuhkan banyak pelarut, proses terbentuknya ekstrak kental lebih cepat. Pada ekstraksi 156,77 gram serbuk kering daun sirih kering diperoleh ektrak kental 11 gram (rendamannya sebesar 7\%). Sedangkan pada ekstraksi 512,63 gram serbuk biji alpukat, diperoleh ekstrak 
kental etanol biji alpukat sebanyak 16 gram (rendamannya sebesar 3.12\%).

\section{Uji pendahuluan}

Sebelum dilakukan uji efektifitas kombinasi ekstrak daun sirih merah dan biji alpukat, dilakukan uji pendahuluan dengan tujuan untuk mencari konsentrasi dari ekstrak daun sirih merah dan ekstrak biji alpukat yang optimal dalam menghambat pertumbuhan $C$. albicans. Pada uji pendahuluan konsentrasi ekstrak daun sirih merah dan ekstrak biji alpukat masing-masing dibuat dalam 5 seri konsentrasi, yaitu 10\%, 20\%, 40\%, 80\%, dan $100 \%$. Diameter zona hambat dalam dilihat pada Tabel 1.
Berdasarkan data uji pendahuluan pada Tabel I, konsentrasi ekstrak daun sirih merah dan ekstrak biji alpukat yang optimum dalam menghambat pertumbuhan $C$. albicans adalah $10 \%$. Semakin tinggi konsentrasi ekstrak ternyata daya hambatnya semakin kecil. Hal ini diduga adanya faktor kejenuhan. Pada saat membran/cakram sudah jenuh dengan larutan ekstrak pada konsentrasi tertentu maka membran tidak bisa lagi mengabsorbsi zat aktif dari ekstrak. Disamping itu, diduga adanya sifat toksik dari pelarut DMSO (Dimetil Sulfoksida). Sehingga adanya pelarut tersebut dapat meningkatkan daya hambat ekstrak biji Alpukat maupun daun sirih merah

Tabel 1. Diameter Zona Hambat Ekstrak Biji Alpukat dan Ekstrak Daun Sirih Merah terhadap Pertumbuhan C. albicans

\begin{tabular}{cccc}
\hline \multirow{2}{*}{ Konsetrasi } & $\mathrm{N}$ & \multicolumn{2}{c}{$\begin{array}{c}\text { Rata-rata deameter zona bening } \\
(\mathrm{mm})\end{array}$} \\
\cline { 3 - 4 } & & $\begin{array}{c}\text { ekstrak biji } \\
\text { alpukat }\end{array}$ & $\begin{array}{c}\text { ekstrak daun } \\
\text { sirih merah }\end{array}$ \\
\hline $10 \%$ & 5 & 2 & 1.2 \\
$20 \%$ & 5 & 1,6 & 1 \\
$40 \%$ & 5 & 0,8 & 0.2 \\
$80 \%$ & 5 & 1.2 & 0.2 \\
$100 \%$ & 5 & 0.6 & 0.4 \\
\hline
\end{tabular}

Konsentrasi optimum ekstrak biji Alpukat maupun daun sirih merah berbeda dengan penelitian sebelumnya. Pada penelitian sebelumnya konsentrasi ekstrak daun sirih merah dan biji alpukat yang paling optimal untuk menghambat pertumbuhan Candida albican masingmasing konsentrasi 40\% dan 80\% (Astuti, 2012; Dewi, 2013). Terdapat beberapa faktor lain yang bisa menyebabkan hasil penelitian ini tidak sama dengan penelitian yang sebelumnya. Faktor-faktor tersebut antara lain kemungkinan karena faktor kandungan zat aktif yang ada ditanaman tersebut tidak adekuat akibat pengaruh perbedaan geografis, serta kemungkinan Candida albicans yang sudah resisten.
Kemampuan ekstrak biji alpukat untuk menghambat Candida albicans disebabkan oleh adanya kandungan senyawa polifenol, flavonoid, triterpenoid, kuinon, tanin dan monoterpenoid dan seskuiterpenoid (Dewi dan Sulistyowati, 2013). Kemampuan daya hambat esktrak biji alpukat lebih besar dibandingkan esktrak daun sirih kemungkinan disebabkan oleh senyawa-senyaa yang terkandung di dalam biji alpukat tersebut lebih adekuat. Pada daun sirih juga menunjukkana adanya diameter zona hambat, namun tidak sebesar jika menggunakan biji alpukat. Terbentuknya daya antifungi daun ini mungkin disebabkan oleh adanya alkaloid, flavonoid, tanin, dan minyak atsiri. Secara 
biologi alkaloid menyebabkan kerusakan membran sel jamur. Alkaloid akan berikatan kuat dengan ergosterol membentuk lubang sehingga membran sel bocor dan kehilangan beberapa bahan intrasel seperti elektrolit (terutama kalium) dan molekul-molekul kecil. Hal ini mengakibatkan kerusakan yang tetap pada sel dan kematian sel jamur. Flavonoid dilaporkan berperan sebagai antivirus, antibakteri, antifungi, antiradang, dan antialergi. Flavonoid mempunyai senyawa genestein berfungsi menghambat pembelahan atau proliferasi sel jamur. Senyawa ini mengikat protein mikrotubulus dalam sel dan mengganggu fungsi mitosis gelendong sehingga menimbulkan penghambatan pertumbuhan jamur (Astuti, 2012).

Uji efektivitas kombinasi ekstrak daun sirih merah dengan biji alpukat dalam menghambat pertumbuhan C. Albicans

Pada penelitian ini digunakan 5 kelompok yang terdiri dari 2 kelompok kontrol (positif dan negative) dan 3 kelompok perlakuan (ekstrak biji alpukat dengan konsentrasi 10\%, daun sirih merah konsentrasi $10 \%$, kombinasi ekstrak biji alpukat dan daun sirih merah). Daya hambat masing-masing kelompok dapat dilihat pada Grafik 1. Kontrol Positif menggunakan larutan Flukonazol $0.025 \%$ dan kontrol negatifnya menggunakan pelarut DMSO tanpa pengenceran

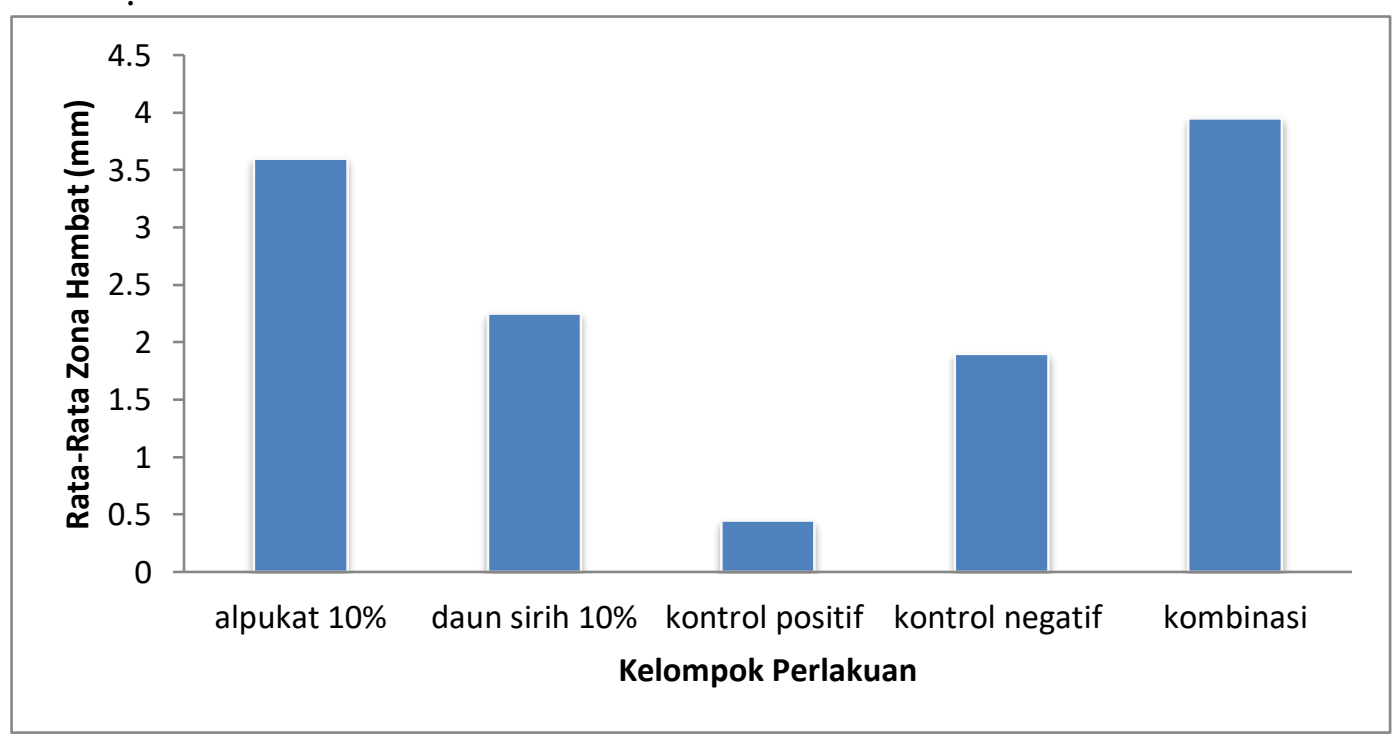

Gambar 1. Diagram Rata - Rata Diameter Zona Hambatan

Tabel 2. Uji Post-Hoc Mann Whitney

\begin{tabular}{cc}
\hline Kelompok Perlakuan & DZH $(\mathrm{mm})$ \\
\hline Kontrol Negatif & $1,90 \pm 0,38^{\mathrm{a}}$ \\
Kontrol Positif & $0,45 \pm 0,53^{\mathrm{b}}$ \\
Ekstrak Biji Alpukat & $4,00 \pm 0,00^{\mathrm{c}}$ \\
Ekstrak Daun Sirih Merah & $2,25 \pm 0,50^{\mathrm{a}}$ \\
Kombinasi & $3,95 \pm 0,30^{\mathrm{c}}$ \\
\hline
\end{tabular}

Keterangan: Superscript a,b,c,d,e dengan huruf yang sama pada kolom variabel berarti tidak terdapat perbedaan yang bermakna $(\mathrm{p}>0,05)$.

Berdasarkan uji normalitas Kolmogorov-Smirnov, data pengukuran diameter zona hambat tiap kelompok perlakuan berdistribusi normal karena memiliki nilai $\mathrm{p}>\alpha$. Sedangkan hasil uji Levene untuk diameter zona hambat 
mempunyai nilai $p=0,009$. Hal ini berarti varians data diameter zona hambat tidak homogen $(p<0,05)$. Sehingga untuk mengetahui ada tidaknya perbedaan antar kelompok perlakuan digunakan uji Kruskal Wallis. Berdasarkann hasil uji Kruskal Wallis, data diameter zona hambat menunjukkan ada perbedaan bermakna antar kelompok perlakuan dengan sig. 0,002 (sig. < 0,05). Perbandingan zona hambat pada masing-masing kelompok dapat dilihat pada Uji Post Hoc (Mann Whitney), dapat dilihat pada Tabel 2.

Kelompok perlakuan 5 (kombinasi ekstrak daun sirih merah dan ekstrak biji alpukat) menunjukkan hasil yang berbeda secara signifikan dengan kelompok ekstrak daun sirih merah 10\%, kontrol positif dan kontrol negatif. DMSO sebagai kontrol negatif memiliki daya hambat yang lebih tinggi dibandingkan kontrol positif dan berbeda secara signifikan. Hal ini memperkuat dugaan pada uji pendahuluan bahwa pelarut DMSO yang digunakan pada penelitian ini bersifat toksik. Hal ini terjadi karena konsentrasi DMSO yang digunakan terlalu tinggi. Sehingga disarankan perlu adanya pengenceran DMSO terlebih dahulu sebelum digunakan sebagai pelarut. Pelarut DMSO $10 \%$ merupakan pelarut organik dan tidak bersifat bakterisidal (Reynolds, 1996)

Adanya penambahan ekstrak biji alpukat pada ekstrak daun sirih merah ternyata dapat menaikkan daya hambat

\section{Kesimpulan}

Berdasarkan hasil penelitian dapat diperoleh kesimpulan bahwa penambahan ekstrak etanol alpukat mampu menaikkan kemampuan ekstrak etanol daun sirih dalam memhambat pertumbuhan Candida albicans. Kombinasi ekstrak daun sirih merah dan ekstrak biji alpukat memiliki daya hambat yang lebih efektivitas dalam menghambat pertumbuhan Candida albicans dibandingkan flukonazol.

\section{Saran}

1. Pengembangan penelitian serupa dapat dilakukan dengan ekstrak daun sirih merah terhadap pertumbuhan $C$. albicans secara signifikan. Hal ini menunjukkan bahwa terjadi aktivitas yang sinergis antara senyawa aktif pada kedua ekstrak tersebut. Namun hasil daya hambat kombinasi masih sedikit dibawah daya hambat ekstrak biji alpukat $10 \%$. untuk manaikkan daya hambat kombinasi ekstrak terhadap pertumbuhan C. albicans perlu dilakukan optimasi komposisi perbandingan jumlah ekstrak daun sirih dan biji alpukat.

Mekanisme antijamur flukonazol sebagai obat antifungi lebih dahulu diketahui dan dipahami, yakni melalui penghambatan enzim yang bergantung pada sitokrom P-450 yang akan mencegah konversi lanosterol ke ergosterol sehingga jumlah ergosterol yang terbentuk akan berkurang. Pengurangan ergosterol yang merupakan komponen utama membran sel jamur akan menyebabkan kerusakan membran sel (Atika, 2010). Pada penelitian ini kelompok Flukonazol sebagai kontrol positif memiliki daya hambat paling rendah dibandingkan kelompok yang lain. Hal ini diduga karena konsentrasi larutan flukonazol yang digunakan terlalu rendah sehingga sifat daya hambatnya lebih rendah dari pelarut DMSO. Disamping itu diduga biakan $C$. albicans pada penelitian ini menunjukkan gejala resistensi terhadap flukonazol.

membandingkan efektifitas daya hambat ekstrak Biji Alpukat dengan antifungi yang lain.

2. Penelitian dengan mempertimbangan "dose effect relationship" pada ekstrak Biji Alpukat untuk mendapatkan gambaran pengaruh pemberian ekstrak Biji Alpukat pada berbagai variasi dosis, sekaligus mengkaji toksisitasnya.

3. Pelarut DMSO yang digunakan dalam penelitian diharapkan diencerkan terlebih dahulu. 


\section{DAFTAR PUSTAKA}

Astuti, O. R. 2012. Uji Daya Antifungi Ekstrak Etanol Daun Sirih Merah (Piper crocatum Ruiz \& Pav) Terhadap Candida albicans ATCC 10231 Secara IN VITRO. Fakultas Kedokteran, Universitas Muhammadiyah Surakarta.

Atika Nur Windi. 2010. Efek Kombinasi Tea Tree Oil (Melaleuca Alternifolia) Dengan Ekstrak Biji Jinten Hitam (Nigella sativa) Terhadap Candida albican In Vitro. Fakultas Kedokteran Sebelas Maret Surakarta.

Dewi, S. R. dan Sulistyowati. 2013. Penggunaan Ekstrak Biji Buah Alpukat (Persea americana Mill.) Sebagai Antibakteri Proteus mirabilis dan Aerobacter aerogenes. Stigma. Vol. 6. No.2. 2013:31-34.

Herliyanti, Endang, Darmani. (2003). Hubungan Antara Pemakaian Akdr Dengan Kandidiasis Vagina di RSUP Dr. Pirngadi Medan. Bagian Ilmu Penyakit Kulit Dan Kelamin Kedokteran Universitas Sumatera Utara.

Khawaja Tahir Mahmood, Mashal Anees dan Ayesha Asghar. Valvular Heart Diseases - Review. J Biomed Sci and Res., Vol 3 (1), 2011, 315-321

Made, Dewa. 2014. Kandidiasis vagina Yang Mendapat Terapi Sistemik dan Topikal: Sebuah Laporan Kasus. vol 3 no 6 (2014):e-jurnal medika udayana.
Prasetyowati. (2009). Hubungan personal hygiene dengan kejadian keputihan pada siswi SMU Muhammadiyah Metro tahun 2009. Medan. Skripsi tidak Dipublikasikan

Rahajeng Putriningrum, Annisaul Khoiriyah. 2014. Analisis Tingkat Pengetahuan Pada Ibu Hamil Trimester Iii Menuju Proses Menyusui. Jurnal Kesehatan Kusuma Husada (Jurnal KesMaDaSka) STIKes Kusuma Husada Surakarta.

Reynolds, J. E. F. 1996. Martindale, The Extra Pharmacopeia $31^{\text {th }}$ Edition. The Royal Pharmaceutical Society Press. London. p : 114 - 117.

Rochani, Nita. 2009. Uji Aktivitas Antijamur Ekstrak Daun Binahong (Anredera cordifolia (Tenore) Steen) terhadap Candida albicans Serta Skrining Fitokimianya. Fakultas Farmasi Universitas Muhammadiyah Surakarta, Surakarta.

Wina, Arniputri, B. Retna. 2015. Identifikasi Komponen Utama Minyak Atsiri Sirih Merah. Biodiversitas Vol.8, No.2. Hal. 136-137.

Zuhrotun, A. 2007. Aktivitas Antidiabetes Ekstrak Etanol Biji Buah Alpukat (Persea americana Mill.) Bentuk Bulat. Fakultas Farmasi, Universitas Padjadjaran. Jatinang 